\title{
Antimicrobial activity of propolis and essential oils and synergism between these natural products
}

Probst IS (1), Sforcin JM (1), Rall VLM (1), Fernandes AAH (2), Fernandes Júnior A (1)

(1) Department of Microbiology and Immunology, Botucatu Biosciences Institute, São Paulo State University (UNESP - Univ Estadual Paulista), Botucatu, São Paulo State, Brazil; (2) Department of Chemistry and Biochemistry, Botucatu Biosciences Institute, São Paulo State University (UNESP - Univ Estadual Paulista), Botucatu, São Paulo State, Brazil.

\begin{abstract}
In the present study, Apis mellifera propolis and essential oils (EOs) obtained from aromatic plants were evaluated as alternative antimicrobials. We aimed to establish the antimicrobial activity of ethanolic extracts of propolis (EEP) from Apis mellifera and of EOs from Caryophyllus aromaticus, Zingiber officinale, Cinnamomum zeylanicum and Mentha piperita against 32 Staphylococcus aureus and Escherichia coli strains from human clinical specimens. The antimicrobials were diluted in agar and the minimal inhibitory concentrations (MIC) were found whereas $\mathrm{MIC}_{90 \%}$ values were calculated. Time-kill curve assays using mixtures containing one quarter of $\mathrm{MIC}_{90 \%}$ for EEP with all EOs as well cinnamon EO were performed. The cinnamon EO was found to be the most efficient, with MIC90\% values of 1.22 and $0.96 \mathrm{mg} \mathrm{x} \mathrm{mL}^{-1}$ respectively against $S$. aureus and E. coli, whereas $\mathrm{MIC}_{90 \%}$ of EEP were 1.86 and $20.12 \mathrm{mg} \mathrm{x} \mathrm{mL}^{-1}$ respectively against $S$. aureus and $E$. coli. The combinations of EEP with ginger and mint EOs, and cinnamon with ginger and clove EOs, showed synergistic effects. Consequently, further studies are necessary to confirm these activities in vivo and to evaluate the phytochemical characteristics of natural products.
\end{abstract}

Key words: Apis mellifera, aromatic plants, ethanolic extract of propolis, Staphylococcus aureus, Escherichia coli.

\section{INTRODUCTION}

The development of multidrug-resistant pathogens has been related to the occurrence of over- and under-dosage of antimicrobials $(1,2)$. One strategy employed to overcome resistance mechanisms is the use of combinations of drugs and several plant extracts, which had exhibited synergistic activity against microorganisms (3). Among the natural sources of antimicrobial agents utilized to treat infectious diseases, propolis and essential oils from aromatic plants were exhaustively studied (4-8).

Propolis has been used since ancient times by numerous populations, including the Assyrians, Greeks, Romans, Incas and Egyptians (9-10). It is a resinous bee product from buds and other parts of plants surrounding the hive, with addition of saliva, waxes and pollen (11-13). Bees mix the original propolis with beeswax and $\beta$-glucosidase that they secrete during propolis collection. The resulting material is used by bees to seal holes in the hives, to exclude draughts, to protect against external invaders and to mummify their carcasses (14). It has been shown that the antimicrobial activity of propolis is attributed to phenolic compounds, especially flavonoids that are widely distributed trough leaves, fruits, seeds and other parts of plants - and which are recognized for their antioxidant activity $(5,15-$ 17). Mantovani et al. (18) evaluated the chemical composition of propolis samples collected in southern and southeastern Brazil, and reported that samples from the south had a higher amount of flavonoids, while the southeastern samples showed a higher amount of phenolic compounds. 
Variations in the composition of propolis extracts are also responsible for different results in antimicrobial activity tests (19-20).

Aromatic plants are used for multiple purposes (e.g., maintaining health, hygiene and life quality) in the traditional culture of many countries such as India and Brazil $(5,21)$. The interest in aromatic plants and their essential oils is due to their numerous antimicrobial compounds with potential to directly or indirectly inhibit bacterial enzyme systems, resulting in bactericidal or bacteriostatic effects $(22,23)$. Sartoratto et al. (24) established that the presence of various chemical compounds in the essential oils of some plants is crucial for their antimicrobial properties.

Eugenol is an active compound from clove essential oils (Caryophyllus aromaticus L., family Myrtaceae), which has been used as analgesic, antispasmodic, bactericidal, fungicidal and antiparasitic agent, as well as antiseptic agent in dentistry. Recent studies have shown the possibility of using clove $\mathrm{EO}$ as a replacement for some chemical additives in the preservation of meat and fish (25-27).

Ginger (Zingiber officinale Roscoe, family Zingiberiaceae) is an important spice used as preservative in food and as an aphrodisiac. Some compounds found in its EO may act in stomach, facilitating digestion and inhibiting nausea and vomiting, and its major constituent is zingiberene $(28,29)$. In India, small pieces of ginger rhizome are mixed with honey and used to treat coughs, sore throat, fever and colds (30).

Peppermint (Mentha piperita L., family Lamiaceae) is utilized in several countries for several purposes, including Brazil, where it is employed as a local anesthetic to relieve cramps, headaches and muscle pain, and for influenza and throat infections, stimulating perspiration and fever. In addition, the plant is used to treat insect bites, and to promote restful sleep and healing. It is also utilized in cooking as a spice for salty foods or flavoring tea. The peppermint EO is consumed worldwide and menthone is of its main components (28). The EO has moderate antimicrobial activity against both gram-positive and gram-negative microorganisms, bactericidal effects against Staphylococcus aureus and Escherichia coli strains (2).

Cinnamon (Cinnamomum zeylanicum Blume, family Lauraceae) was employed by ancient Greeks, Romans and Jews to flavor wine and for religious purposes in India and China. It possess several biological activities such as analgesic, antispasmodic, astringent, aphrodisiac, hypoglycemic, carminative, haemostatic, insecticidal and antiparasitic properties. In folk medicine, it is used in elixirs and liquors for weakness and headaches, with its delicate aroma and sweet and spicy flavor, and it has been used as flavoring in meat and fast food, sauces, confectionery, beverages, pharmaceuticals, dental care products and perfumes, although it can be aggressive to the skin $(28,31)$. More recently, studies on the antimicrobial activity of cinnamon EO from leaves and bark were performed $(32,33)$. Chao et al. (34) reported that EO from cinnamon bark showed antimicrobial activity against several species of fungi, bacteria and viruses tested in clinical trials.

Several studies on the synergism among natural products were carried out $(3,7,8,35$, 36). It is expected that mixtures of propolis and EOs may lead to a better inhibitory action than that achieved by the substance alone (37). Combinations of EOs from several plants were analyzed by Gutierrez et al. (38), in order to find successful interactions among them. These authors also reported that such combinations, especially when oregano was used, were able to potentiate antimicrobial activity against Bacillus cereus, E. coli and Pseudomonas aeruginosa strains in food systems. Although the oils previously tested were not quite the same as those employed in our research, we aimed to verify the in vitro antimicrobial activity of propolis (EEP) from Apis mellifera and essential oils from clove, ginger, cinnamon and peppermint on E. coli and $S$. aureus strains from human specimens. The minimal inhibitory concentration (MIC) was determined through the agar dilution method and the synergism among these natural products was assayed by the time-kill curve method.

\section{MATERIALS AND METHODS}

\section{Ethanolic Extract of Propolis (EEP)}

Propolis samples from Apis mellifera were collected at the experimental farm of the São Paulo State University (UNESP), Botucatu. The ethanolic extract of propolis (EEP) was prepared using $30 \mathrm{~g}$ of raw propolis diluted in $100 \mathrm{~mL}$ of $70 \%$ ethanol. After seven days at room temperature, the EEP was filtered and stored in dark bottles at $4^{\circ} \mathrm{C}$. One milliliter was used to determine the dry weight of EEP by solvent evaporation at $50^{\circ} \mathrm{C}$ (13). 


\section{Essential Oils (EOs)}

EOs of clove (Caryophyllus aromaticus) (inflorescence) and ginger (Zingiber officinale) (fresh rhizomes) were prepared in a clevenger apparatus (model M480, Marconi, Brazil) at our laboratory. Peppermint (Mentha piperita) (leaves) and cinnamon (Cinnamomum zeylanicum) EOs were purchased from a Brazilian company that supplies natural products, where EOs were produced by steam distillation. One milliliter of each natural product was used to determine the dry weight of EEP and the density of EOs (39). These values were used to establish minimal inhibitory concentration (MIC) in $\mathrm{mg} \mathrm{x} \mathrm{mL}^{-1}$ when the susceptibility assays were performed.

\section{Bacterial Strains}

Fifteen strains of $S$. aureus and fifteen of E. coli isolated from human biological material from patients of the Botucatu Medical School, UNESP, were used in the susceptibility assays. American Type Culture Collection (ATCC) strains of each species were used (S. aureus ATCC 33591 and E. coli ATCC 25922) to standardize the microbiological tests. The strains were stored at $-70^{\circ} \mathrm{C}$, and before the susceptibility tests they were inoculated in sheep blood agar (Difco, USA) to establish their viability. This work was approved by the Ethics Research Committee (CER) of UNESP.

\section{Susceptibility Tests}

\section{Minimal inhibitory concentration (MIC)}

The MIC tests were performed by diluting the natural products in agar, as recommended by the CLSI guidelines (40), followed by determining their respective $\mathrm{MIC}_{90 \%}$ values.

Petri dishes containing Mueller-Hinton agar (MHA) (Difco, USA) plus Tween $80(0.3 \% \mathrm{v} / \mathrm{v})$ and the natural products achieved concentrations ranging from $0.025 \%$ to $3.5 \% \mathrm{v} / \mathrm{v}$ for the EOs, and from $0.1 \%$ to $14 \% \mathrm{v} / \mathrm{v}$ for EEP and $70 \%$ ethanol. These concentrations were transformed into $\mathrm{mg}$ $\mathrm{x} \mathrm{mL} \mathrm{m}^{-1}$ according to EOs and ethanol densities and EEP dry weight. The bacterial strains were inoculated in brain heart infusion (BHI) (Difco, USA) $\left(37^{\circ} \mathrm{C}\right.$ for 24 hours) and standardized at 0.5 on the McFarland scale to achieve a bacterial suspension of circa $10^{5}$ colony forming units (CFU $\times \mathrm{mL}^{-1}$ ). Thirty-two bacterial strains (16 S. aureus and 16 E. coli) were inoculated in Petri dishes using a Steers multiple inoculator and after 24 hour at $37^{\circ} \mathrm{C}$ the MIC values were recorded (presence or absence of colonies of each of the bacterial strains) and the $\mathrm{MIC}_{90 \%}$ values were established. The positive controls of growth of the bacterial strains in the absence of natural antimicrobials were performed by inoculating strains on Petri dishes containing MHA plus 3\% of Tween 80 and incubation at $37^{\circ} \mathrm{C}$ for 24 hours.

\section{Time-kill curve and interactions between natural antimicrobials}

Bacterial counts of $S$. aureus and E. coli strains by the pour plate method on plate count agar (PCA) (Difco, USA) were performed in order to establish any synergistic effects when natural products were added to BHI plus Tween $80 \%$ $(0.3 \% \mathrm{v} / \mathrm{v})$. The mixtures reached values of one quarter of the $\mathrm{MIC}_{90 \%}$ in natural products when EEP was combined with EOs and cinnamon EO with other EOs. The $10^{5} \mathrm{CFU} \times \mathrm{mL}^{-1}$ bacterial suspensions were inoculated in BHI tubes (time zero) and after $1.5,3,6,9$ and 24 hours at $37^{\circ} \mathrm{C}$. Aliquots of each culture were recovered and plated on PCA by the pour plate method. After 24 hours at $37^{\circ} \mathrm{C}$, the $\mathrm{CFU} \times \mathrm{mL}^{-1}$ values were recorded. As in previous susceptibility tests in which the values of MIC were discovered, control assays were carried out and normal bacterial growth curve was also assessed when CFU x mL $\mathrm{mL}^{-1}$ was achieved.

\section{Statistical Analysis}

Data were analyzed using analysis of variance, followed by the Student's t-test, and $\mathrm{p}>0.05$ indicated no significant difference between treatments. The statistical software SAS version 9.0, licensed by UNESP in 2009, was employed.

\section{RESULTS AND DISCUSSION}

\section{Essential Oils and EEP}

EOs had different density values (Table 1), clove EO presented the highest value (1.101 mg x $\left.\mathrm{mL}^{-1}\right)$ and ginger EO had the lowest density (896 $\mathrm{mg} \times \mathrm{mL}^{-1}$ ). During the extraction process, clove oil accumulated in the bottom of the Fiorentino distiller bottle, revealed the expected higher density of this oil. The dry weight of the EEP (172.2 $\mathrm{mg} \times \mathrm{mL}^{-1}$ ) was in agreement with Fernandes Júnior et al. (13). In a scale of increasing densities and concentrations, the values were as follow: EEP $<70 \%$ ethanol $<$ ginger $\mathrm{EO}<$ peppermint $\mathrm{EO}<$ cinnamon $\mathrm{EO}<$ clove $\mathrm{EO}$. 
Table 1. Density values ( $\mathrm{mg} \mathrm{x} \mathrm{mL}^{-1}$ ) of essential oils (EO) and $70 \%$ ethanol and EEP (ethanolic extract of propolis) dry weigh $\left(\mathrm{mg} \mathrm{x} \mathrm{mL}^{-1}\right)$

\begin{tabular}{c|c|c|c|c|c}
\hline Ginger EO & Peppermint EO & Clove EO & Cinnamon EO & EEP & Ethanol 70\% \\
\hline 896.6 & 918.9 & 1101.0 & 1021.9 & 172.2 & 790.0 \\
\hline
\end{tabular}

Table 2. Mean and standard deviation of minimal inhibitory concentration (MIC) values ( $\mathrm{mg} \mathrm{x} \mathrm{mL}^{-1}$ ) for all antimicrobials against $S$. aureus and E. coli strains

\begin{tabular}{c|c|c|c|c|c|c}
\hline Bacteria & Ginger & Peppermint & Clove & Cinnamon & EEP & $70 \%$ Ethanol \\
\hline S. aureus & $\begin{array}{c}1.1920 \pm 0.75 \\
\mathrm{aA}\end{array}$ & $\begin{array}{c}3.67 \pm 1.50 \\
\mathrm{aA}\end{array}$ & $\begin{array}{c}1.27 \pm 0.48 \\
\mathrm{aB}\end{array}$ & $\begin{array}{c}1.15 \pm 0.35 \\
\mathrm{aB}\end{array}$ & $\begin{array}{c}1.54 \pm 0.62 \\
\mathrm{aA}\end{array}$ & $\begin{array}{c}71.68 \pm 2.09 \\
\mathrm{bB}\end{array}$ \\
\hline E. coli & $\begin{array}{c}7.0523 \pm 3.13 \\
\mathrm{bB}\end{array}$ & $\begin{array}{c}31.25 \pm 7.11 \\
\mathrm{~dB}\end{array}$ & $\begin{array}{c}1.27 \pm 0.48 \\
\mathrm{aB}\end{array}$ & $\begin{array}{c}0.99 \pm 0.13 \\
\mathrm{aB}\end{array}$ & $\begin{array}{c}19.24 \pm 2.20 \\
\mathrm{CB}\end{array}$ & $\begin{array}{c}70.12 \pm 3.02 \\
\mathrm{eB}\end{array}$ \\
\hline
\end{tabular}

Different small letters indicate differences among the natural products $(p \leq 0.05)$.

Different capital letters indicate differences among the bacterial strains $(p \leq 0.05)$.

\section{Antimicrobial Activity of Natural Products}

EOsandEEPhad similar resultsfor antimicrobial activity against $S$. aureus (Table 2) with no significant differences, and $70 \%$ ethanol control showed the lowest inhibitory activity. Cinnamon and clove EOs presented higher inhibitory activities against $E$. coli, followed by ginger EO and EEP. Peppermint EO was less active than the other EOs. Once again, 70\% ethanol showed the lowest inhibitory activity against E. coli. Table 3 presents the $\mathrm{MIC}_{90 \%}$ values and the effects of MIC against the bacterial strains. All strains challenged in the susceptibility assays showed normal growth on control Petri plates with MHA plus Tween 80 $(0.3 \% \mathrm{v} / \mathrm{v})$ when inoculated and incubated under the same conditions of the treatment assays. Thus, the absence of growth or absence of colonies of bacterial strains on Petri dishes containing natural antimicrobials can be explained by the inhibitory effect of antimicrobials and not due to nutritional or environmental failures during the cultivation.

The $\mathrm{MIC}_{90 \%}$ values were distinct for the different bacterial strains. Peppermint EO (6.18 $\mathrm{mg} \times \mathrm{mL}^{-1}$ ) showed a great inhibitory effect on S. aureus compared to its action on E. coli ( 30 $\mathrm{mg} \times \mathrm{mL}^{-1}$ ), while regarding EEP, the $\mathrm{MIC}_{90 \%}$ values were $1.86 \mathrm{mg} \mathrm{x} \mathrm{mL}^{-1}$ and $20.12 \mathrm{mg} \mathrm{x} \mathrm{mL}^{-1}$ respectively against $S$. aureus and E. coli (Table 3 ). Ethanol, the EEP solvent, had no effect on EEP antimicrobial activity.

The structure of gram-negative bacterial wall, which presents an outer complex membrane, including two lipid bilayers, could be the reason for the obtained results $(41,42)$. These layers comprise physical barriers between microorganisms and the environment, preventing interactions of the bacterial cell with harmful substances. Gram-

Table 3. $\mathrm{MIC}_{90 \%}$ and range of MIC values $\left(\mathrm{mg} \mathrm{x} \mathrm{mL}^{-1}\right.$ ) of EO, EEP and 70\% ethanol against 16 S. aureus and 16 E. coli strains

\begin{tabular}{c|c|c|c|c|c|c|c}
\hline \multirow{2}{*}{ Bacteria } & & Ginger & Peppermint & Clove & Cinnamon & EEP & $\begin{array}{c}70 \% \\
\text { Ethanol }\end{array}$ \\
\hline \multirow{2}{*}{ S. aureus } & MIC90\% & 1.7 & 6.2 & 1.6 & 1.2 & 1.8 & 72.4 \\
\cline { 2 - 8 } & $\begin{array}{c}\text { Range of } \\
\text { MIC }\end{array}$ & $0.6-2.7$ & $2.7-6.3$ & $0.5-2.2$ & $1.2-2.0$ & $0.7-3.4$ & $60.8-72.4$ \\
\hline \multirow{2}{*}{ E. coli } & MIC 90\% & 8.7 & 30.0 & 1.6 & 1,0 & 20.1 & 72.3 \\
\cline { 2 - 8 } & $\begin{array}{c}\text { Range of } \\
\text { MIC }\end{array}$ & $0.8-13.5$ & $4.6-33.0$ & $0.5-2.2$ & $0.5-1.0$ & $\begin{array}{c}15.5- \\
20.6\end{array}$ & $66.3-72.4$ \\
\hline
\end{tabular}


positive bacteria present only one relatively permeable membrane, rendering them more susceptible to interactions with the environment (43). Another possible cause of the resistance against phytotherapeutics is the presence of multiresistant sites that promote the synthesis and secretion of amphipathic toxins (37).

In addition to the morphological differences among bacteria, there must be variations in the chemical compositions of EOs. Some plants have active ingredients that can easily penetrate bacteria, and some fail to interact with the bacterial cell, reducing their antimicrobial potential. Thus, the composition of EOs must be chemically analyzed to allow a study on the interactions alone. The chemical composition of EOs may present large variations according to several factors including age, time of harvest and origin of the plant, which may interfere with the presence/absence of some of the active chemical compounds, as well as may influence in the volatilization of these compounds (44).

\section{Synergism between Natural Products}

The time-kill curves of natural products alone, with their $\mathrm{MIC}_{90 \%}$ values (or one quarter of
$\mathrm{MIC}_{90 \%}$ values) for EEP and EOs against $S$. aureus and E. coli strains are shown in Figures 1 and 2 . The survival rates of $S$. aureus and $E$. coli strains in mixtures containing one quarter of $\mathrm{MIC}_{90 \%}$ values of cinnamon $\mathrm{EO}$ with ginger, clove and peppermint EOs are displayed in Figures 3 and 4.

Synergism was shown in various combinations and three or more log reductions in the CFU $\mathrm{x}$ $\mathrm{mL}^{-1}$ of the initial inoculum provided evidence of bactericidal effect (45). Bacteriostatic activity was recorded when the scores were near the original number without going over the test scores obtained in the positive control of bacteria. Thus, $\mathrm{MIC}_{90 \%}$ values established were bactericidal for clove, ginger and peppermint EOs, while cinnamon EO, EEP and 70\% ethanol were bacteriostatic against $S$. aureus strains. Clove and cinnamon EOs showed bactericidal effects, while ginger and peppermint EOs as well as EEP and 70\% ethanol showed bacteriostatic effect against $E$. coli strains.

Synergism with bacteriostatic effects was established in the assays when EEP was combined with ginger and peppermint EO, and in the mixtures with cinnamon and clove EOs and cinnamon and peppermint EOs on S. aureus

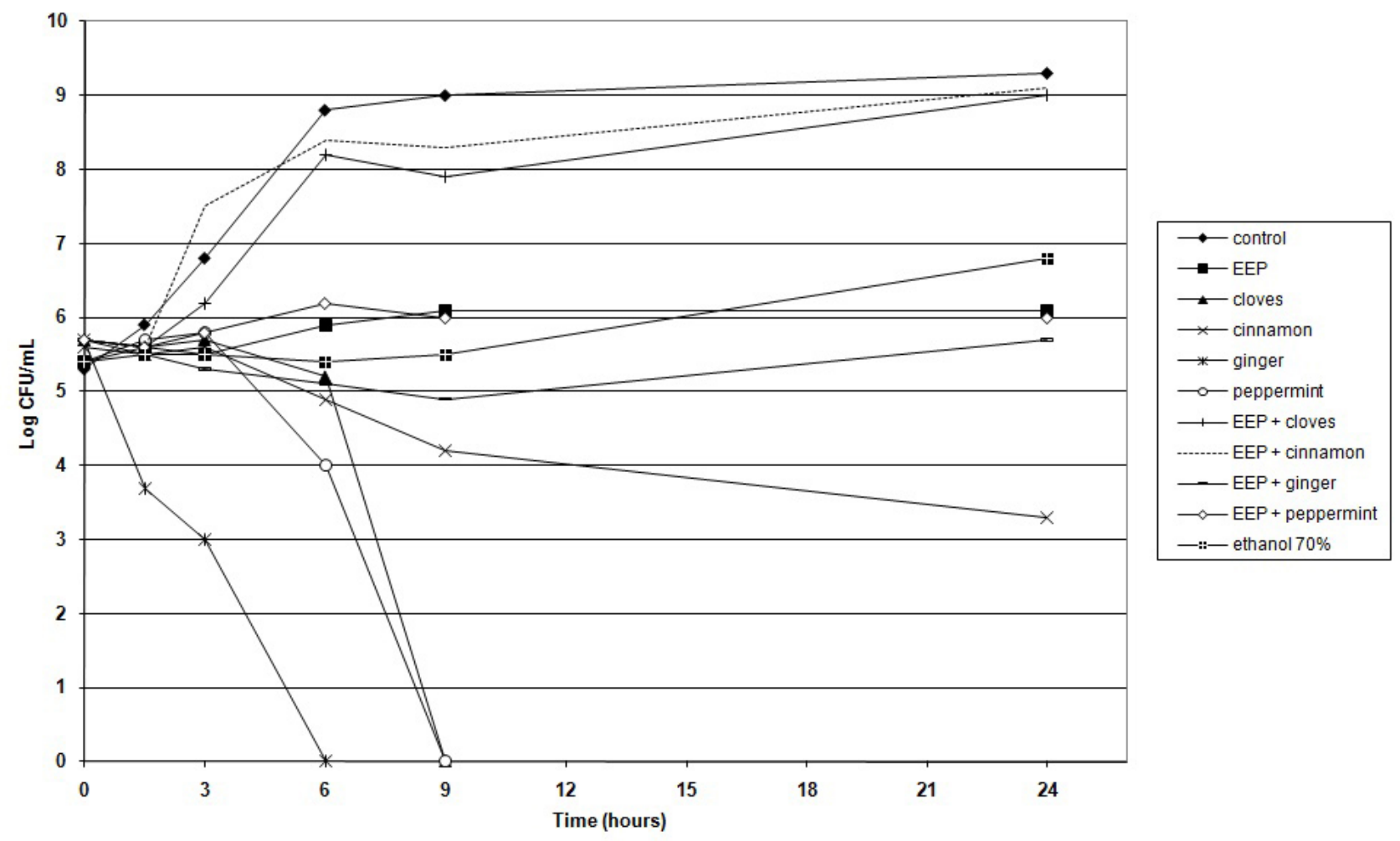

Figure 1. Log CFU $\times \mathrm{mL}^{-1}$ values in the time-kill curve of $\mathrm{MIC}_{90 \%}$ values of the products alone and in combination with one quarter of $\mathrm{MIC}_{90 \%}$ values for $\mathrm{EEP}$ with essential oils against $S$. aureus strain. 


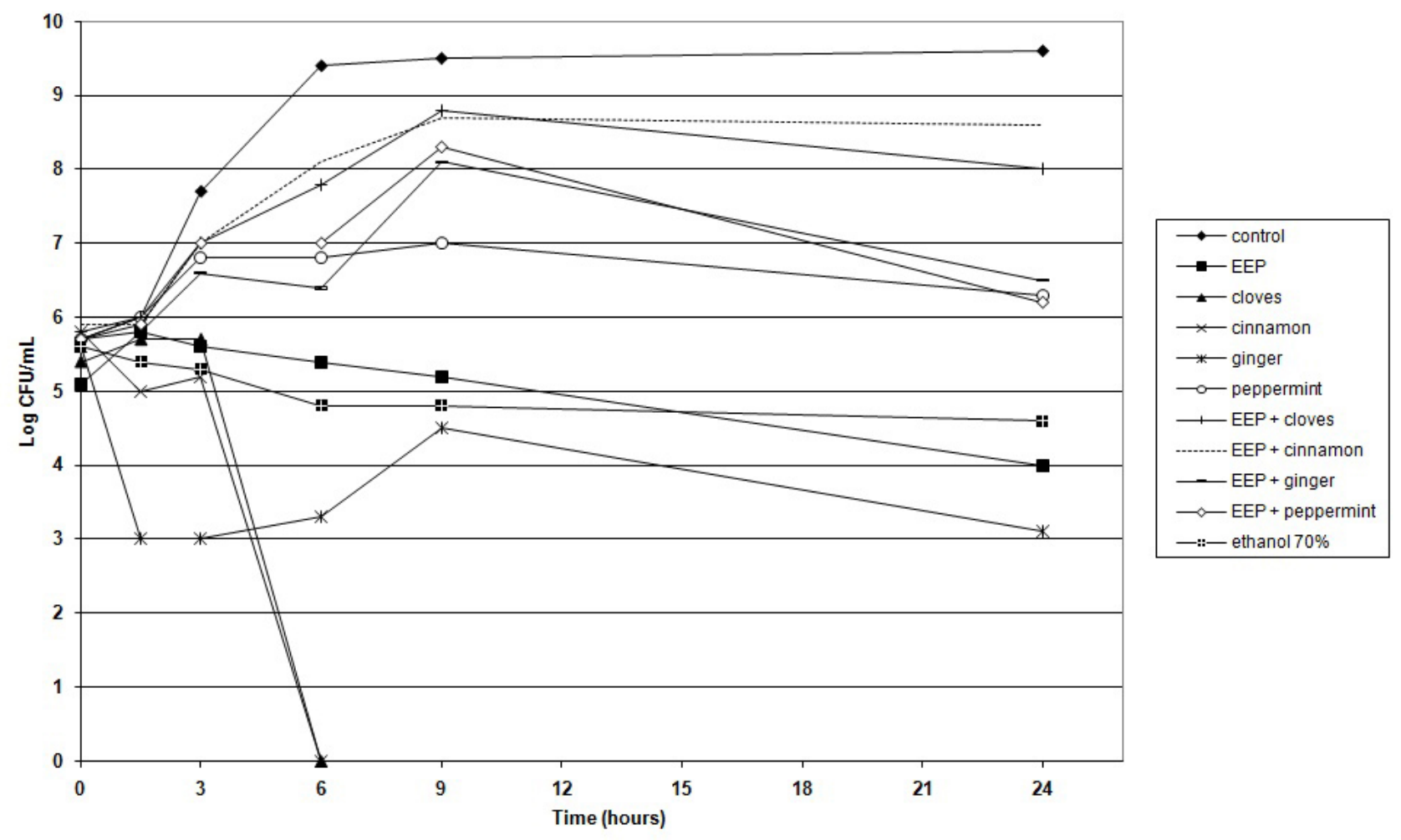

Figure 2. Log CFU $\times \mathrm{mL}^{-1}$ values in the time-kill curve of $\mathrm{MIC}_{90 \%}$ values of the products alone and in combination with one quarter of $\mathrm{MIC}_{90 \%}$ values for $\mathrm{EEP}$ with essential oils against $E$. coli strain.

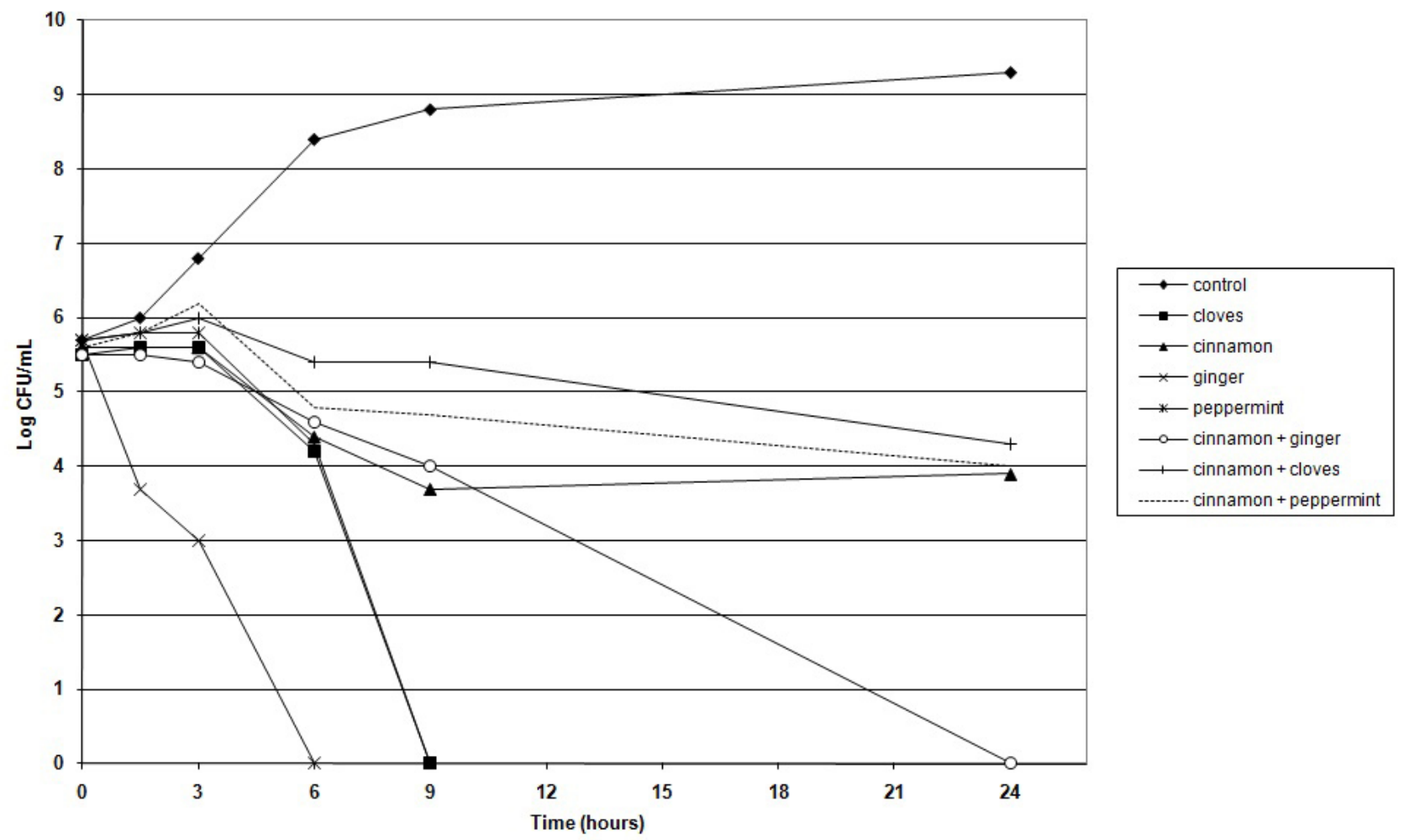

Figure 3. Log CFU x mL ${ }^{-1}$ values in the time-kill curve of $\mathrm{MIC}_{90 \%}$ values of the products separately and in combination with one quarter of $\mathrm{MIC}_{90 \%}$ values for cinnamon oil with essential oils against $\mathrm{S}$. aureus strain. 


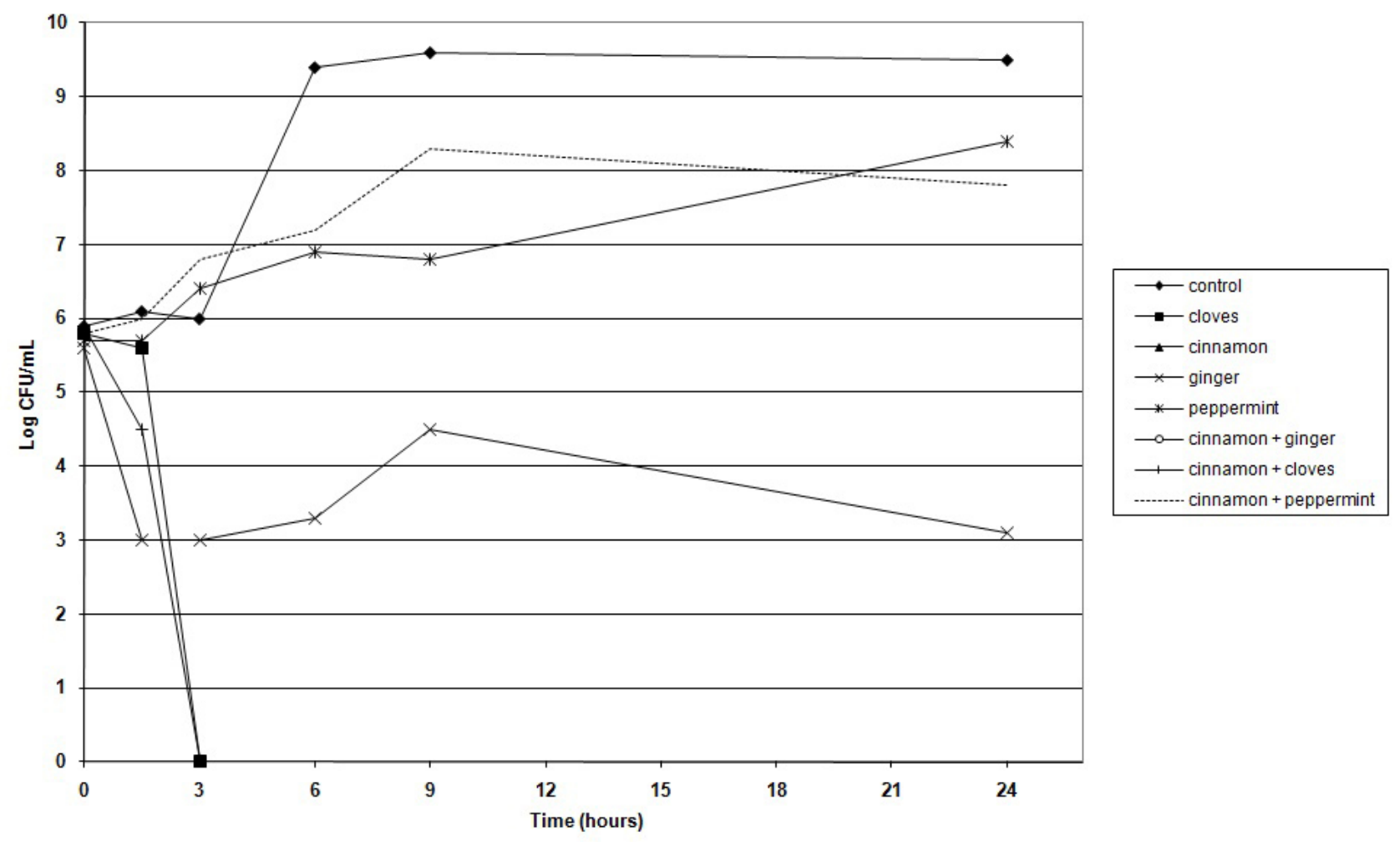

Figure 4. Log CFU $x$ mL-1 values in the time kill curve of MIC90\% values of the products separately and in combination with one quarter of MIC90\% values for cinnamon oil with essential oils against E. coli strain

growth (Figure 1). Synergism with bactericidal effect was also verified in the combination of cinnamon and ginger EOs (Figure 3) against S. aureus. Whereas there were significant differences in the antimicrobial activities of the natural products on the studied bacterial strains, synergism with bacteriostatic effect against $E$. coli strains by EEP with ginger and peppermint EOs and bactericidal effects of cinnamon EO with ginger and clove EOs are shown in Figures 2 and 4, respectively. Al-Bayati (46) reported that combinations of thyme (Thymus vulgaris) and anise (Pimpinella anisum) EOs showed inhibitory activity against pathogenic bacteria, and that these EOs were more efficient than the drug Maxipime in the assays. These authors also found that the association with EO potentiated the effects of the compounds of each plant, assuring that microorganism were inhibited by various chemical compounds at the same time, increasing the antibacterial activity of the products. This phenomenon was evident against $P$. aeruginosa strains, a pathogen resistant to isolated EOs, methanolic extracts and antimicrobial drugs.
Moreover, the evaluation of the interactions between EEP and EOs should be clarified because Garedewa et al. (37) reported that the use of propolis at concentrations below the MIC could increase the growth of the microorganisms, whereas at higher levels they may inhibit or even kill them. This event is known as "hormesis", and was first mentioned by Calabrese and Baldwin (47). Thus, because the present study provides information on propolis extract, which is frequently used for treatment of some common infectious diseases, and if employed at low concentrations, we believe that it can even worsen the disease.

\section{CONCLUSIONS}

Our results showed antibacterial properties in all of the natural products studied. Moreover, combinations of EEP with ginger and peppermint EOs, and cinnamon with ginger and clove EOs showed synergistic effects that may be valuable in the development of phytotherapeutics with antimicrobial actions against gram-positive and gram-negative microorganisms. Since the tests 
were performed in vitro, further studies focusing on the safe use of these substances in humans and animals, especially against $S$. aureus and $E$. coli infections, should be conducted. In addition, there is a global tendency towards the development of herbal drugs from different mixtures of natural products aiming at the standardization of active compounds in these products.

\section{ACKNOWLEDGEMENTS}

The authors thank The State of São Paulo Research Foundation (FAPESP) and Foundation for the Development of UNESP (FUNDUNESP) for the financial support. Thanks are also due to Prof. Dr. Ricardo de Oliveira Orsi who kindly provided the samples used in the assays.

\section{COPYRIGHT}

(C) CEVAP 2011

\section{SUBMISSION STATUS}

Received: November 16, 2011.

Accepted: February 11, 2011.

Abstract published online: February 16, 2011.

Full paper published online: May 31, 2011.

\section{CONFLICTS OF INTEREST}

There is no conflict.

\section{FINANCIAL SOURCE}

The State of São Paulo Research Foundation (FAPESP) and Foundation for the Development of UNESP (FUNDUNESP) provided the financial grants.

\section{ETHICS COMMITTEE APPROVAL}

The present study was approved by the Ethics Research Committee (CER) of the Botucatu Medical School, São Paulo State University (UNESP - Univ Estadual Paulista), Botucatu, São Paulo State, Brazil.

\section{CORRESPONDENCE TO}

ARY FERNANDES JÚNIOR, Departamento de Microbiologia e Imunologia, Instituto de Biociências, UNESP, Botucatu, SP, Brasil. Phone: +55 14 38116058. Email: ary@ibb.unesp.br.

\section{REFERENCES}

1. Vargas AC, Loguercio AP, Witt NM, Costa MM, Silva MS, Viana LR. Alcoholic propolis extract: antimicrobial activity. Cienc Rural. 2004;34(1):159-63.
2. Schelz Z, Molnar J, Hohmann J. Antimicrobial and antiplasmid activities of essential oils. Fitoterapia. 2006;77(4):279-85.

3. Hemaiswarya S, Kruthiventi AK, Doble M. Synergism between natural products and antibiotics against infectious diseases. Phytomedicine. 2008;15(8):63952.

4. Kujumgiev A, Tsvetkova I, Serkedjieva Y, Bankova V, Christov R, Popov S. Antibacterial, antifungal and antiviral activity of propolis of different geographic origin. J Ethnopharmacol. 1999;64(3 ):235-40.

5. Packer JF, Luz MMS. Evaluation and research method for natural products inhibitory activity. Rev Bras Pharmacogn. 2007;17(1):102-7.

6. Silva MTN, Ushimaru PI, Barbosa LN, Cunha MLRS, Fernandes Júnior A. Antibacterial activity of plant essential oils against Staphylococcus aureus and Escherichia coli strains isolated from human specimens. Braz J Medicinal Plants. 2009;11(3):25762.

7. Zago JAA, Ushimaru PI, Barbosa LN, Fernandes Júnior A. Synergism between essential oils and antimicrobial drugs against Staphylococcus aureus and Escherichia coli from humans infections. Rev Bras Pharmacogn. 2009;19(4):828-33.

8. Silva NCC, Fernandes Júnior A. Biological properties of medicinal plants: a review of their antimicrobial activity. J Venom Anim Toxins incl Trop Dis. 2010;16(3):402-13.

9. Pereira AS, Seixas FRMS, Aquino Neto FR. Propolis: anos de pesquisa e suas perspectivas futuras. Quim Nova. 2002;25(2):321-6.

10. Castaldo S, Capasso F. Propolis, an old remedy used in modern medicine. Fitoterapia. 2002;73(suppl 1):S1-6.

11. Pinto MS, Faria JE, Message D, Cassini STA, Pereira CS, Gioso MM. Efeito de extratos de própolis verde sobre bactérias patogênicas isoladas do leite de vacas com mastite. Braz J Vet Res Anim Sci. 2001;38(6):27883.

12. Fernandes Júnior A, Balestrin ECD, Cunha MRLS. Atividade anti Staphylococcus aureus de extratos de própolis (EP) de Apis mellifera preparados com diferentes concentrações de etanol. Rev Ciênc Farm. 2003;24(2):147-52.

13. Fernandes Júnior A, Balestrin EC, Betoni JE, Orsi Rde O, da Cunha Mde L, Montelli AC. Propolis: anti-Staphylococcus aureus activity and synergism with antimicrobial drugs. Mem Inst Oswaldo Cruz. 2005;100(5):563-6.

14. Pietta PG, Gardana C, Pietta AM. Analytical methods for quality control of propolis. Fitoterapia. 2002;73 Suppl 1:S7-20.

15. Menezes H. Propolis: uma revisão dos recentes estudos de suas propriedades farmacológicas. Arq Inst Biol. 2005;72(3):405-11.

16. Angelo PM, Jorge N. Compostos fenólicos em alimentos: uma breve revisão. Rev Inst Adolfo Lutz. 2007;66(1):1-9.

17. Simões CC, Araújo DB, Araújo RPC. Estudo in vitro e ex vivo da ação de diferentes concentrações de extratos de própolis frente aos microrganismos 
presentes na saliva de humanos. Rev Bras Farmacogn. 2008;18(1):84-9.

18. Mantovani RP, Rall VLM, Batalha JEN, Fernandes AAH, Fernandes Júnior A. Anti-coagulase-negative Staphylococcus activity of ethanolic extracts of propolis from two Brazilian regions and synergism with antimicrobial drugs by E-Test method. J Venom Anim Toxins incl Trop Dis. 2008;14(2):357-65.

19. Fernandes Júnior $\mathrm{A}$, Lopes $\mathrm{MMR}$, Colombari V, Monteiro ACM, Vieira EP. Antimicrobial activity of Apis mellifera propolis from three regions of Brazil. Ciênc Rural. 2006;36(1):294-7.

20. Gonsalez GZ, Orsi RO, Fernandes Júnior A, Rodrigues P, Funari SRC. Antibacterial activity of propolis collected in different regions of Brazil. J Venom Anim Toxins incl Trop Dis. 2006;12(2):276-84.

21. Sofia PK, Prasad R, Vijay VK, Srivastava AK. Evaluation of antibacterial activity of Indian spices against common foodborne pathogens. Int J Food Sci Technol. 2007;42(8):910-5.

22. Duarte MC, Figueira GM, Sartoratto A, Rehder VLG, Delarmelina C. Anti-Candida activity of Brazilian medicinal plants. J Ethnopharmacol. 2005;97(2):305-11.

23. Ernandes FMPG, Garcia-Cruz CH. Atividade antimicrobiana de diversos óleos essenciais em microrganismos isolados do meio ambiente. Bol Centro Pesqui Process Aliment. 2007;25(2):193-206.

24. Sartoratto A, Machado ALM, Delarmelina C, Figueira GM, Duarte MCT, Rehder VLG. Composition and antimicrobial activity of essential oils from aromatic plants used in Brazil. Braz J Microbiol. 2004;35(4):275-80.

25. Burt S. Essential oils: their antibacterial properties and potential applications in foods - a review. Int J Food Microbiol. 2004;94(3):223-53.

26. Oussalah M, Caillet S, Saucier L, Lacroix M. Antimicrobial effects of selected plant essential oils on the growth of a Pseudomonas putida strain isolated from meat. Meat Sci. 2006;73(2):236-44.

27. Oussalah M, Caillet S, Saucier L, Lacroix M. Inhibitory effects of selected plant essential oils on the growth of four pathogenic bacteria: E. coli O157:H7, Salmonella Typhimurium, Staphylococcus aureus and Listeria monocytogenes. Food Control. 2007;18(5):414-20.

28. Nepomuceno R. Viagem ao fabuloso mundo das especiarias. 5th ed. Rio de Janeiro: José Olympio; 2007. $250 \mathrm{p}$.

29. Maia NB, Bovi AO, Duarte FR. Extraction and analysis of ginger essential oil: processing and drying. Bragantia. 1991;50(1):83-92.

30. Jamir TT, Sharma HK, Dolui AK. Folklore medicinal plants of Nagaland, Índia. Fitoterapia. 1999;70(4):395-401.

31. Jayatilaka A, Poole SK, Poole CF, Chichila TMP. Simultaneous micro steam distillation/solvent extraction for the isolation of semivolatile flavor compounds from cinnamon and their separation by series coupled-column gas chromatography. Anal Chim Acta. 1995;302(2-3):147-62.

32. Maidment C, Dyson A, Haysom. A study into the antimicrobial effects of cloves (Syzgium aromaticum) and cinnamon (Cinnamomum zeylanicum) using discdiffusion assay. Nutrition Food Sci. 2006;36(4):225-30.
33. Senhaji O, Faid M, Kalalou I. Inactivation of Escherichia coli O157:H7 by essential oil from Cinnamomum zeylanicum. Braz J Infec Dis. 2007;11(2):234-6.

34. Chao SC, Young DG, Oberg CJ. Screening for inhibitory activity of essential oils on selected bacteria, fungi and viruses. J Essential Oil Res. 2000;12(5):63949.

35. Betoni JE, Mantovani RP, Barbosa LN, Di Stasi LC, Fernandes Júnior A. Synergism between plant extract and antimicrobial drugs used on Staphylococcus aureus diseases. Mem Inst Oswaldo Cruz. 2006;101(4):38790.

36. Rosato A, Vitali C, De Laurentis N, Armenise D, Antonietta Milillo M. Antibacterial effect of some essential oils administered alone or in combination with norfloxacin. Phytomedicine. 2007;14(11):727-32.

37. Garedew A, Schmolz E, Lamprechtb I. Microbiological and calorimetric investigations on the antimicrobial actions of different propolis extracts: an in vitro approach. Thermochimica Acta. 2004;422(1-2):11524.

38. Gutierrez J, Barry-Ryan C, Bourke P. The antimicrobial efficacy of plant essential oil combinations and interactions with food ingredients. Int $\mathrm{J}$ Food Microbiol. 2008;124 (1):91-7.

39. Fonseca P, Librand APL. Avaliação das características físico-químicas e fitoquímicas de diferentes tinturas de barbatimão (Stryphnodendron barbatiman). Rev Bras Cienc Farm. 2008;44(2):271-7.

40. Clinical and Laboratory Standards Institute/NCCLS. Performance standards for antimicrobial susceptibility testing; Fifteenth Informational Supplement. CLSI/ NCCLS document M 100-S15. Wayne, PA: CLSI; 2005.

41. Nieva Moreno MI, Isla MI, Cudmani NG, Vattuone MA, Sampietro AR. Screening of antibacterial activity of Amaicha del Valle (Tucumán, Argentina) propolis. J Ethnopharmacol. 1999;68(1-3):97-102.

42. Scazzocchio F, D'Auria FD, Alessandrini D, Pantanella F. Multifactorial aspects of antimicrobial activity of propolis. Microbiol Res. 2006;161(4):327-33.

43. Perussi JR. Photodynamic inactivation of microorganisms. Quim Nova. 2007;30(4):988-94.

44. Gobbo-Neto L, Lopes NP. Medicinal plants: factors of influence on the content of secondary metabolites. Quim Nova. 2007;30(2):374-38.

45. Wootton M, MacGowan AP, Walsh TR. Comparative bactericidal activities of daptomycin and vancomycin against glycopeptide-intermediate Staphylococcus aureus (GISA) and heterogeneous GISA isolates. Antimicrob Agents and Chemoter. 2006;50(12):4195-7.

46. Al-Bayati FA. Synergistic antibacterial activity between Thymus vulgaris and Pimpinella anisum essential oils and methanol extracts. J Ethnopharmacol. 2008; 116(3):403-6.

47. Calabrese EJ, Baldwin LA. Hormesis as a biological hypothesis. Environ Health Perspect. 1998;106(Suppl 1):357-62. 